
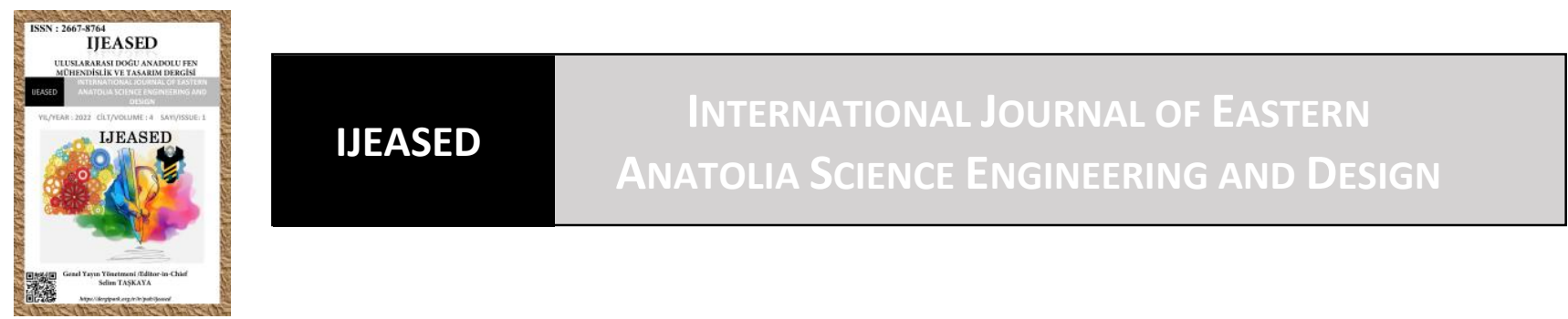

\author{
Uluslararası Doğu Anadolu Fen Mühendislik ve Tasarım Dergisi \\ ISSN: 2667-8764 , 4(1), 32-52, 2022 \\ https://dergipark.org.tr/tr/pub/ijeased
}

Araştırma Makalesi / Research Article

Doi: $10.47898 /$ ijeased.1010079

\title{
Ulusal Mermer İşletmesi Temsilcilerinin Mermer Atığı Oluşumuna Yönelik Gözlemleri ve Atık Değerlendirme Konusundaki Düşünceleri Üzerine Bir Araştırma
}

\author{
Seza ŞİMŞEK ${ }^{1}$, Z. Sevgen PERKER ${ }^{2 *}$
}

${ }^{1}$ Konya Kültür Varlıklarını Koruma Bölge Kurulu, 42030, Konya, Türkiye.

${ }^{2}$ Bursa Uludağ Üniversitesi, Mimarlık Fakültesi, Mimarlık Bölümü, 16059, Bursa, Türkiye.

\begin{tabular}{|c|c|c|}
\hline Yazar Kimliği / Author ID (ORCID Number) & \multicolumn{2}{|c|}{ Makale Süreci / Article Process } \\
\hline $\begin{array}{l}\text { "Sorumlu Yazar / Corresponding author: } \\
\text { zsperker@uludag.edu.tr } \\
\text { (iD) https://orcid.org/0000-0003-2055-3967 , S. Şimşek } \\
\text { (iD) https://orcid.org/0000-0002-6640-111X , Z. S. Perker }\end{array}$ & $\begin{array}{l}\text { Geliş Tarihi / Received Date } \\
\text { Revizyon Tarihi / Revision Date : } \\
\text { Kabul Tarihi / Accepted Date : } \\
\text { Yayım Tarihi / Published Date : }\end{array}$ & $\begin{array}{l}15.10 .2021 \\
04.12 .2021 \\
06.02 .2022 \\
15.07 .2022\end{array}$ \\
\hline
\end{tabular}

Alıntı / Cite : Şimşek, S., Perker, Z.S. (2022). Ulusal Mermer İşletmesi Temsilcilerinin Mermer Atığı Oluşumuna Yönelik Gözlemleri ve Atık Değerlendirme Konusundaki Düşünceleri Üzerine Bir Araştırma, Uluslararası Doğu Anadolu Fen Mühendislik ve Tasarım Dergisi, 4(1), 32-52.

\section{Özet}

Mermer üretim faaliyetleri sırasında, önemli miktarlarda mermer atığı ortaya çıkmaktadır. Atığın değerlendirilmesi, doğal kaynakların verimli ve sürdürülebilir kullanımının yanı sıra, çevre sorunlarının azaltılması açısından da gereklidir. Atıkların değerlendirilmesi konusunda, pek çok faktörün yanı sıra, işletmeyi temsil eden kişilerin konuya olan yaklaşımları da önem taşımaktadır. Bu bağlamda araştırmanın başlıca amacı; mermer işletmelerini temsil eden kişilerin, çalıştıkları işletmelerde mermer atığı oluşumuna ilişkin gözlemlerinin ve mermer atığının değerlendirilmesine ilişkin düşüncelerinin tespit edilmesidir. Ayrıca mermer işletmelerinin çeşitli özelliklerinin belirlenmesi, işletme temsilcilerinin mermer atıkları ve değerlendirilmesi konusundaki gözlemleri, düşünceleri ve işletme özellikleri arasında, istatistiksel açıdan anlamlı ilişki olup olmadığının tespit edilmesi de amaçlanmaktadır. Araştırmada, anket formu ile elde edilen veriler üzerinde, frekans analizleri ki kare uyum iyiliği testleri ve ki kare bağımsızlık testleri yapılmıştır. Araştırma sonucunda mermer atığını değerlendirmeyen işletme sayısının, üretime giren mermerin \% 30 - \% 70’u arasındaki bir oranda atık haline geldiğini gözlemleyen temsilci sayısının, mermer atıklarının yapı malzemesi üretiminde ve farklı sektörlerde kullanılamayacağını düşünen temsilci sayısının beklenen değerden anlamlı bir şekilde fazla olduğu belirlenmiştir. Ayrıca işletme temsilcilerinin, atık satışını, atığın değerlendirilmesi olarak görmedikleri de tespit edilmiştir.

Anahtar Kelimeler: Malzeme, Yapı Malzemesi, Taş, Mermer, Atık. 


\title{
A Research On The Observations Of The National Marble Enterprise Representatives On The Formation Of Marble Waste And Their Opinions On Waste Evaluation
}

\begin{abstract}
Significant amounts of marble waste are generated during marble production activities. Evaluation of the generated waste is necessary for the efficient and sustainable use of natural resources and reducing environmental problems. In the evaluation of wastes, besides many factors, the approach of the persons representing the enterprise to the subject is also important. In this context, this study aims to determine the observations of the people representing the marble enterprises regarding the formation of marble waste in the enterprises they work for and their thoughts on evaluating the marble waste. In addition, within the research scope, it aims to determine the various characteristics of the marble enterprises to determine whether there is a statistically significant relationship between the observations and thoughts of the business representatives about marble waste and the business characteristics. In the study, frequency analysis, chisquare goodness of fit tests, and chi-square independence tests were performed on the data obtained with the questionnaire. As a result of the research, it has been determined that the number of enterprises that do not evaluate the marble waste, the number of representatives who observe that the marble entering the production turns into at a rate of between $30 \%$ and $70 \%$ waste, and the number of representatives who think that marble waste cannot be used in the production of building materials or different sectors are significantly higher than the expected value. In addition, it has been determined that the business representatives do not see the waste sale as the evaluation of the waste.
\end{abstract}

Keywords: Material, Building Material, Stone, Marble, Waste.

\section{Giriş}

Tüm dünyada artan yapı üretimi, pek çok malzemenin yanı sıra mermere olan gereksinimi de arttırmıştır. Mermer, üretimi sırasında önemli oranda atık meydana getiren bir malzemedir. Ocaktan çıkartılan mermerin yapıda kullanılacak ürün haline getirilmesi sürecinde pek çok işlem gerçekleşmekte, çeşitli boyutlarda mermer atığı oluşmaktadır. Onargan'a göre üretime giren mermerin yaklaşı1 \% 30'u net ürüne dönüşmekte, \% 70’i ise atık haline gelmektedir (Onargan, 2007). Literatürde atık miktarının üretime giren ürünün \% 75'ine kadar ulaştığına dair bilgiler de bulunmaktadır (Sağlam Çitoğlu ve Bayraktar, 2018).

Mermer ocaklarından mermerin çıkartılmasında ve blok haline getirilmesinde farklı teknikler kullanılmaktadır. Ocaklarda atık oluşmasında; mermerin doğal yapısındaki kırık ve çatlaklar, damarlar, boşluklar, kristal doku, foliasyon (tabakalanma / yapraklanma) düzlemleri ve fosillerin yanı sıra ocağın jeolojik yapısına uygun olmayan üretim metodunun seçilmesi gibi nedenler etkili olmaktadır (Dağl1, 2014). Mermerin ocaktan çıkartılması aşamasında, biçimsiz ve büyük boyutlu mermer atıkları olan molozlar meydana gelmektedir. Mermer, ana kütleden ayrıldıktan sonra blok mermer standartlarına ulaşılabilmesi için sayalama işlemine tabi tutulmaktadır. Bu işlemin ardından genellikle kapak adı verilen parça şeklinde mermer atıkları oluşur (Bilensoy, 2010). Mermer ocaklarından getirilen bloklar, işleme tesislerinde; levha üretimi için levha hattında, plaka ve fayans üretimi için plaka ve fayans hattında, belirli boyutlarda kesilirler. Bu sırada düzgün geometrik 
şekillerde elde edilemeyen parçalar, paledyen atık oluşturmaktadır. Mermerin ocaktan çıkartılması ve işlenmesi sürecinin her aşamasında oluşan $2 \mathrm{~mm}$ 'nin altındaki atıklar ise mermer tozu olarak isimlendirilmektedir (Akkoyun ve Ankara, 2007).

Mermer blok üretimi ve mermerin işlenmesi sırasında ortaya çıkan mermer atıkları;

- Toprağın su emme kapasitesini düşürerek, toprak verimini azaltabilmekte, bitki varlığına zarar verebilmekte,

- Hava kirliliği oluşturarak insan ve çevre sağlığını olumsuz etkileyebilmekte,

- $\mathrm{Su}$ kaynaklarına karışarak suyun kalitesini bozabilmekte ve suyun depolanmasını zorlaştırabilmekte,

- Toprakta uzun süre kaldığında, suyun akışını zorlaştırarak yer altı su kaynaklarını olumsuz etkileyebilmekte,

- Görsel kirliliğe neden olabilmektedir (Bilgin ve Koç, 2010).

Başta çevre sorunlarının azaltılması olmak üzere pek çok açıdan, ortaya çıkan mermer atıklarının değerlendirilmesi büyük önem taşımaktadır (Ersoy vd., 2015). Mermer atıklarının beton, seramik, gazbeton, tuğla, kireç, suni mermer, boya, çelik, cam, derz dolgu malzemesi, parke taşı ve kompozit yap1 malzemesi üretiminde kullanılabildiğini ortaya koyan çeşitli araştırmalar bulunmaktadır. Ayrıca mermer atıklarının; zemin stabilizasyonunda, plastik malzeme üretim sürecinde, ahşap malzeme yüzeyinin şekillendirilmesinde de kullanılabildiğini belirten çeşitli çalışmalar olduğu bilinmektedir (Akın, 2007; Arel, 2016; Bilensoy, 2010; Boztaş, 2009; Ceylan ve Mança, 2013; Dağl1, 2014; Ersoy vd., 2015; Filiz vd., 2010; Günaydın vd., 2016; Keleştemur vd., 2014; Kocabağ, 2018; Sağlam Çitoğlu ve Bayraktar, 2018; Sofuoğlu vd., 2013; Sütçü vd., 2015; Taner, 2012; Taşgın, 2014; Tennich vd., 2015; Topçu vd., 2009; Ulubeyli ve Artır, 2015; Yıldız, 2008; Zhang, 2013).

Mermer atıklarının, mermerin içerdiği kalsit minerali nedeniyle, çeşitli endüstrilerdeki kalsit gereksinimini karşılamakta da kullanılabildiğini belirten araştırmalar bulunmaktadır. Bu bağlamda mermer atıkları metalurji, kimya, kâğıt, şeker, kozmetik sektörlerinde, zirai kireçtaşı, zirai toprak ve zemin ayarlama işlerinde, hayvan yemi ve gübre sanayiinde de kullanım alanı bulabilmektedir (Ceylan, 2000; Geçgil, 1988; Kavas ve Kibıcı, 2001).

Mermer atıklarının değerlendirilmesi konusu, pek çok faktörün yanı sıra işletmeyi temsil eden çalışanların çevresel bilinç ve duyarlılıkları ile yakından ilişkilidir. Konu ile ilgili mevzuatın önemli bir parçası olan "Maden Atıkları Yönetmeliği” nin genel hükümler, görev, yetki ve yükümlülükler bölümünde, işletmenin ve dolayısıyla da işletmenin bir parçası olan çalışanların sorumluluklarına 
açıkça işaret edilmektedir (Maden Atıkları Yönetmeliği, 2015). Bu bağlamda mermer işletmesini temsil eden çalışanların, mermer atığına ilişkin gözlemleri ve mermer atığının değerlendirilmesi konusundaki düşünceleri önem kazanmaktadır. İlgili literatürde, mermer işletmelerini temsil eden çalışanların, çalıştıkları işletmelerde oluşan mermer atığına ilişkin gözlemlerine ve mermer atığının değerlendirilmesi konusundaki düşüncelerine değinen herhangi bir çalışmaya rastlanmamıştır. $\mathrm{Bu}$ bağlamda bu araştırmanın başlıca amacı; ulusal mermer işletmelerini temsil eden kişilerin, çalıştıkları işletmelerde mermer atığı oluşumuna ilişkin gözlemlerinin ve mermer atığının değerlendirilmesine ilişkin düşüncelerinin mevcut haliyle betimlenmesidir. Araştırmanın diğer amaçları arasında; ulusal mermer işletmelerinin çeşitli özelliklerinin belirlenmesi, işletme temsilcilerinin atık değerlendirme konusundaki düşünceleri ile işletme özellikleri ve temsilcilerin mermer atığı oluşumuna ilişkin gözlemleri arasında, istatistiksel açıdan anlamlı ilişki olup olmadığının tespit edilmesi de yer almaktadır.

\section{Yöntem}

Nicel yöntemin benimsendiği araştırma kapsamında; aşağıdaki sorulara yanıt aranmıştır:

- $\quad$ Ulusal mermer işletmelerinin özellikleri nelerdir?

- Ulusal mermer işletmelerinde çalışan işletme temsilcilerinin, işletmelerinde mermer atığı oluşumuna ilişkin gözlemleri nelerdir?

- Ulusal mermer işletmelerinde çalışan işletme temsilcilerinin, işletmelerinde oluşan mermer atığının değerlendirilmesine ilişkin düşünceleri nelerdir?

- Ulusal mermer işletmesi temsilcilerinin, işletmelerinde oluşan mermer atığının değerlendirilmesine ilişkin düşünceleri ile işletme özellikleri arasında istatistiksel açıdan anlamlı ilişki var mıdır?

- Ulusal mermer işletmesi temsilcilerinin, işletmelerinde oluşan mermer atığının değerlendirilmesine ilişkin düşünceleri ile temsilcilerin mermer atığı oluşumuna ilişkin gözlemleri arasında istatistiksel açıdan anlamlı ilişki var mıdır?

\subsection{Araştırma Evreni}

Araştırmanın evrenini TÜYAP Bursa 4. Uluslararası Blok Mermer Fuarı'na katılan ve konu ile ilgili faaliyet gösteren 77 adet ulusal mermer işletmesinin temsilcisi oluşturmaktadır. Araştırmaya 
katılan 77 işletme temsilcisinin \% 9'unun 20-29 yaş aralığında, \% 47'sinin 30- 39 yaş aralığında, \% 42'sinin 40 -49 yaş aralığında; \% 2'sinin ise 50-59 yaş ve üzeri bireyler oldukları belirlenmiştir.

Araştırma kapsamında görüşülen işletme temsilcilerinin mermer sektöründe sahip oldukları deneyim yıl bazında incelendiğinde ise; görüşülen işletme temsilcilerinin \% 19'unun 0-5 yıl, \% 27 'sinin 6 - 10 y1l, \% 17'sinin 11 - 15 y1l, \% 25'inin 16 - 20 y1l, \% 12'sinin ise 21 y1l ve üzeri deneyime sahip oldukları öğrenilmiştir. Verilere göre, görüşülen işletme temsilcilerinin mermer sektöründe 5 yıldan daha fazla deneyime sahip olanlarının toplam oranı \% 81'dir.

Araştırma kapsamında görüşülen işletme temsilcilerinin, \% 57'si temsil ettiği işletmenin çalışanı, \% 34’ü temsil ettiği işletmenin ortağ ya da sahibi, \%9'u ise temsil ettiği işletmenin yöneticisi rolü ile görev yapmaktadırlar.

\subsection{Veri Toplama Aracı}

Literatür taraması sonucunda, araştırma sorularının yanıtlanmasını sağlamak üzere bir anket formu oluşturulmuş ve işletme temsilcileri ile görüşmeler, sözü edilen anket formu aracılığı ile gerçekleştirilmiştir. Oluşturulan anket formunda; TÜYAP Bursa 4. Uluslararası Blok Mermer Fuarı'na katılan ulusal mermer işletmelerinin özellikleri; işletme temsilcilerinin, işletmelerinde mermer atığı oluşumuna ilişkin gözlemleri ile işletme temsilcilerinin, işletmelerinde oluşan mermer atığının değerlendirilmesine ilişkin düşünceleri hakkında bilgi edinilmesini sağlayacak sorulara yer verilmiştir.

\subsection{Veri Analizi}

Araştırma kapsamında anket formu ile elde edilen nominal veriler kodlanarak SPSS 23 paket programına girilmiştir. Betimsel analizler kapsamında; frekans analizi ile frekans dağılımlarının anlamlı olup olmadığının tespiti için ki-kare uyum iyiliği testleri yapılmıştır. İlişkisel analizler kapsamında ise, araştırma sorularına yanıt aramak üzere belirlenen değişkenler arasında ki-kare bağımsızlık testleri gerçekleştirilmiştir. Ki-kare bağımsızlık testleri sonucunda ilişkili olduğu tespit edilen değişkenlerin arasındaki ilişkinin gücü Phi ve Cramer V katsayısı dikkate alınarak yorumlanmıştır. Ki-kare test koşullarının sağlanamadığı durumlarda Fisher Exact testi yapılmış ve sonuçları değerlendirilmiştir. Tüm testler \% 95 güven aralığında gerçekleştirilmiştir.

\section{Bulgular}

Araştırmanın bu bölümü, "Mermer İşletmelerinin Özellikleri Hakkındaki Bulgular”, "İş̧letme Temsilcilerinin, İşletmelerinde Mermer Atığı Oluşumuna İlişkin Gözlemleri Hakkındaki Bulgular”, “İşletme Temsilcilerinin, İşletmelerinde Oluşan Mermer Atığının Değerlendirilmesine İlişkin 
Düşünceleri Hakkındaki Bulgular” ve “İlişkisel Bulgular” olmak üzere dört başlık altında ele alınarak sunulmuştur.

\subsection{Mermer İşletmelerinin Özellikleri Hakkındaki Bulgular}

Araştırma kapsamında temsilcileri ile görüşme yapılan mermer işletmelerinin \% 40’1 Marmara Bölgesi'nde, \% 27'si Ege Bölgesi'nde, \% 14'ü İç Anadolu Bölgesi’nde, \% 11'i Akdeniz Bölgesi'nde, \% 8'i ise Karadeniz Bölgesi, Doğu Anadolu Bölgesi ve Güneydoğu Anadolu Bölgesi’nde faaliyet göstermektedir (Şekil 1). Ki-kare uyum iyiliği testi sonucuna göre, temsilcileri ile görüşme yapılan mermer işletmelerinin faaliyet gösterdiği bölgeler arasında gözlenen farklar anlamlıdır $\left(\mathrm{X}^{2}(4\right.$, $\mathrm{n}=77)=28,390 ; \mathrm{p}=0,000$ ). Marmara Bölgesi'nde faaliyet gösteren işletme sayısı, beklenen değerden anlamlı bir şekilde fazladır.

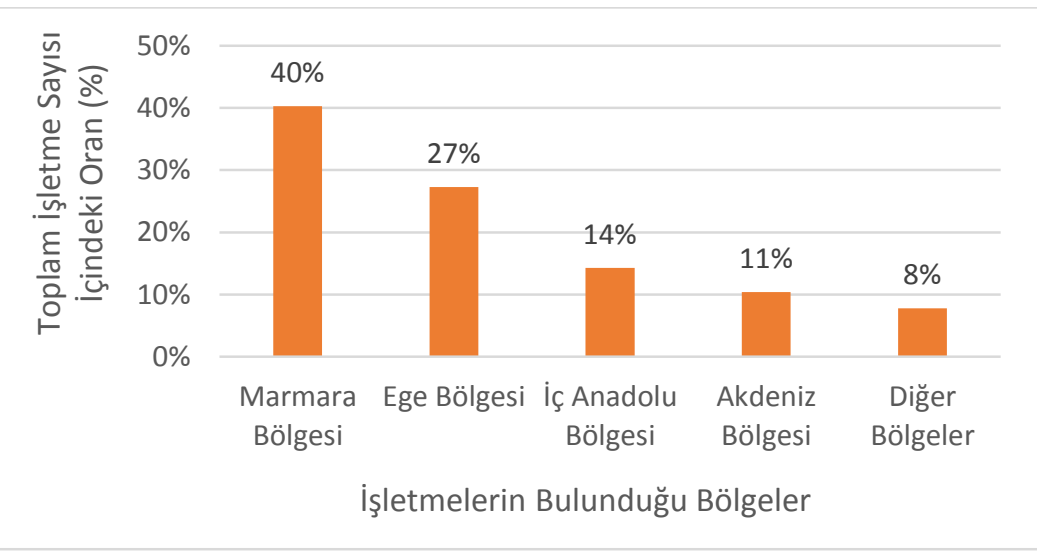

Şekil 1. İşletmelerin bölgelere göre dağılımı

Temsilcisi ile görüşme yapılan işletmelerin \% 30’u 2001-2010 yılları arasında, \% 23’ü 2011 yılı ve sonrasinda, \% 19,5'u 1981-1990 yılları arasında, \% 19,5'u 1991-2000 yılları arasında, \% 8'i ise 1980 yılı ve öncesinde kurulmuştur (Şekil 2). Ki-kare uyum iyiliği testi sonucuna göre, işletmelerin kuruluş yılları arasında gözlenen farklar anlamlıdır $\left(X^{2}(4, n=77)=9,948 ; p=0,041\right) .2001$ yılı ve sonrasında kurulmuş olan işletme sayısı, beklenen değerden anlamlı bir şekilde fazladır. 


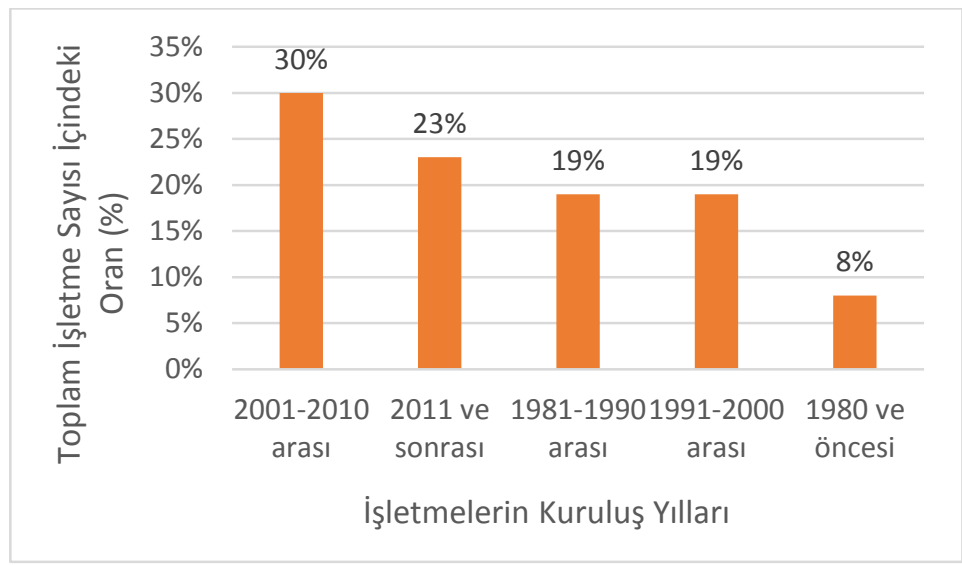

Şekil 2. İşletmelerin kuruluş yıllarına göre dağılımı

Araştırma kapsamına alınan işletmelerin \% 47'si yılda $10000 \mathrm{~m}^{3}$ veya üzerinde mermer üretimi yapmaktadır. İşletmelerin \% 39'u yılda 5000-9999 $\mathrm{m}^{3}$ arasında, \% 14'ü ise yılda $5000 \mathrm{~m}^{3}$ ' den daha az miktarda mermer üretimi yapmaktadır (Şekil 3). Ki-kare uyum iyiliği testi sonucuna göre, işletmelerin mermer üretim miktarları arasında gözlenen farklar anlamlıdır $\left(X^{2}(2, n=77)=13,273\right.$; $\mathrm{p}=0,001) .10000 \mathrm{~m}^{3}$ ve üzerinde mermer üretimi yapan işletme sayısı beklenen değerden anlamlı bir şekilde fazladır.

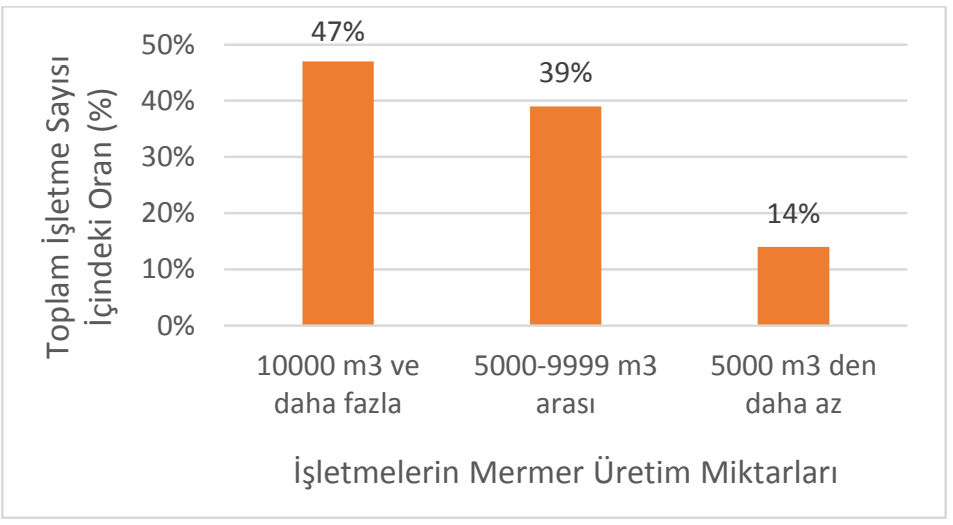

Şekil 3. İşletmelerin mermer üretim miktarlarına göre dağılımı

Temsilcisi ile görüşülen işletmelerin \% 49’u y1lda $10000 \mathrm{~m}^{3}$ veya üzerinde mermer satış1 yapmaktadır. İşletmelerin \% 36'sı yılda 5000-9999 $\mathrm{m}^{3}$ arasında, \% 14'ü ise yılda $5000 \mathrm{~m}^{3}$ 'den daha az miktarda mermer satışı yapmaktadır (Şekil 4). Ki-kare uyum iyiliği testi sonucuna göre, işletmelerin mermer satış miktarları arasında gözlenen farklar anlamlıdır $\left(X^{2}(2, n=77)=14,519\right.$; $\mathrm{p}=0,001) .10000 \mathrm{~m}^{3}$ ve üzerinde mermer satışı yapan işletme sayısı, beklenen değerden anlamlı bir şekilde fazladır. 


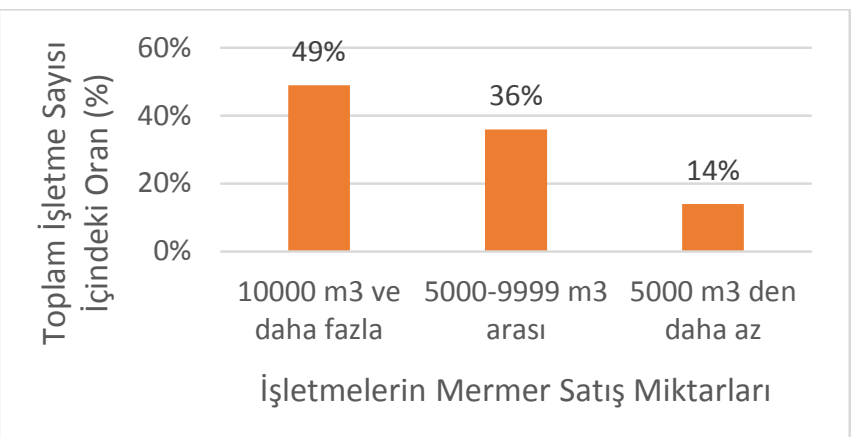

Şekil 4. İşletmelerin mermer satış miktarlarına göre dağglımı

İşletmelerin \% 65'i hem blok hem de levha mermer, \% 27'si sadece blok mermer, \% 8'i ise sadece levha mermer üretimi yapmaktadır (Şekil 5). Ki-kare uyum iyiliği testi sonucuna göre, hem blok hem de levha mermer üretimi yapan işletme sayısı, beklenen değerden anlamlı bir şekilde fazladir $\left(X^{2}(2, n=77)=38,987 ; p=0,000\right)$.

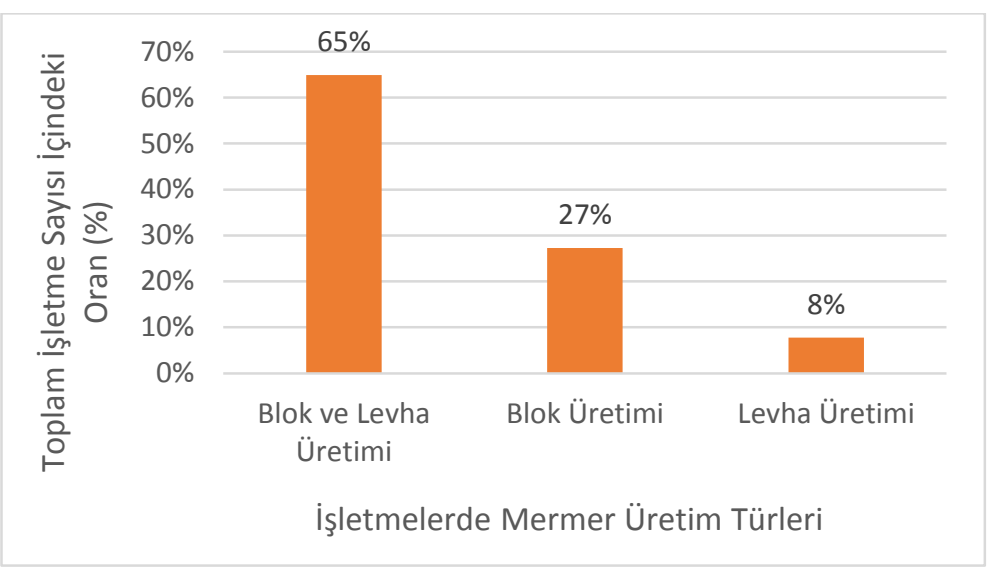

Şekil 5. İşletmelerin ürettikleri mermer türüne göre dağılımı

Temsilcisi ile görüşülen işletmelerin \% 40’1 sadece levha mermer, \% 33’ü blok ve levha mermer, \% 27'si ise sadece blok mermer satışı yapmaktadır (Şekil 6). Ki-kare uyum iyiliği testi sonucuna göre, işletmelerin sattıkları mermer türlerine göre sayıları, beklenen değerden anlamlı bir şekilde farklı değildir $\left(X^{2}(2, n=77)=1,974 ; p=0,373\right)$. 
Şimşek, S., ve Perker, Z.S., Uluslararası Doğu Anadolu Fen Mühendislik ve Tasarım Dergisi / International Journal of Eastern Anatolia Science Engineering and Design (IJEASED)

(2022) 4(1): 32-52

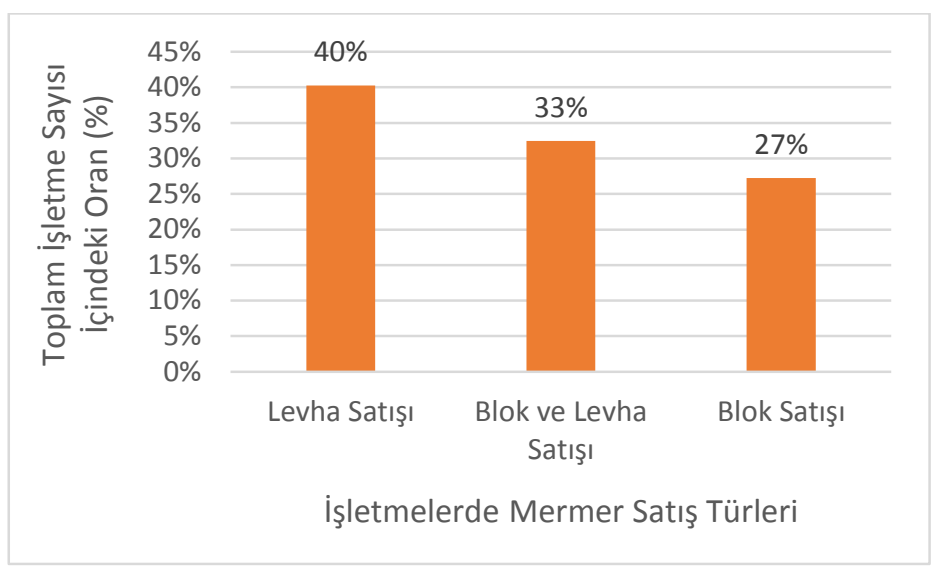

Şekil 6. İşletmelerin sattıkları mermer türüne göre dağılımı

İşletmelerin mermer üretiminde kullandıkları işleme yöntemlerinin kullanımına ilişkin dağılım Şekil 7'de, işleme yöntemlerinin kullanımına ilişkin ki-kare uyum iyiliği testi sonuçları ise Tablo 1'de görülmektedir. Elde edilen verilere göre; testere ile kesme, honlama, cilalama, doğal boyutlandırma, eskitme, doldurma ve alevle yakma yöntemlerini kullanan işletme sayısının beklenen değerden anlamlı bir şekilde fazla olduğu söylenebilmektedir.

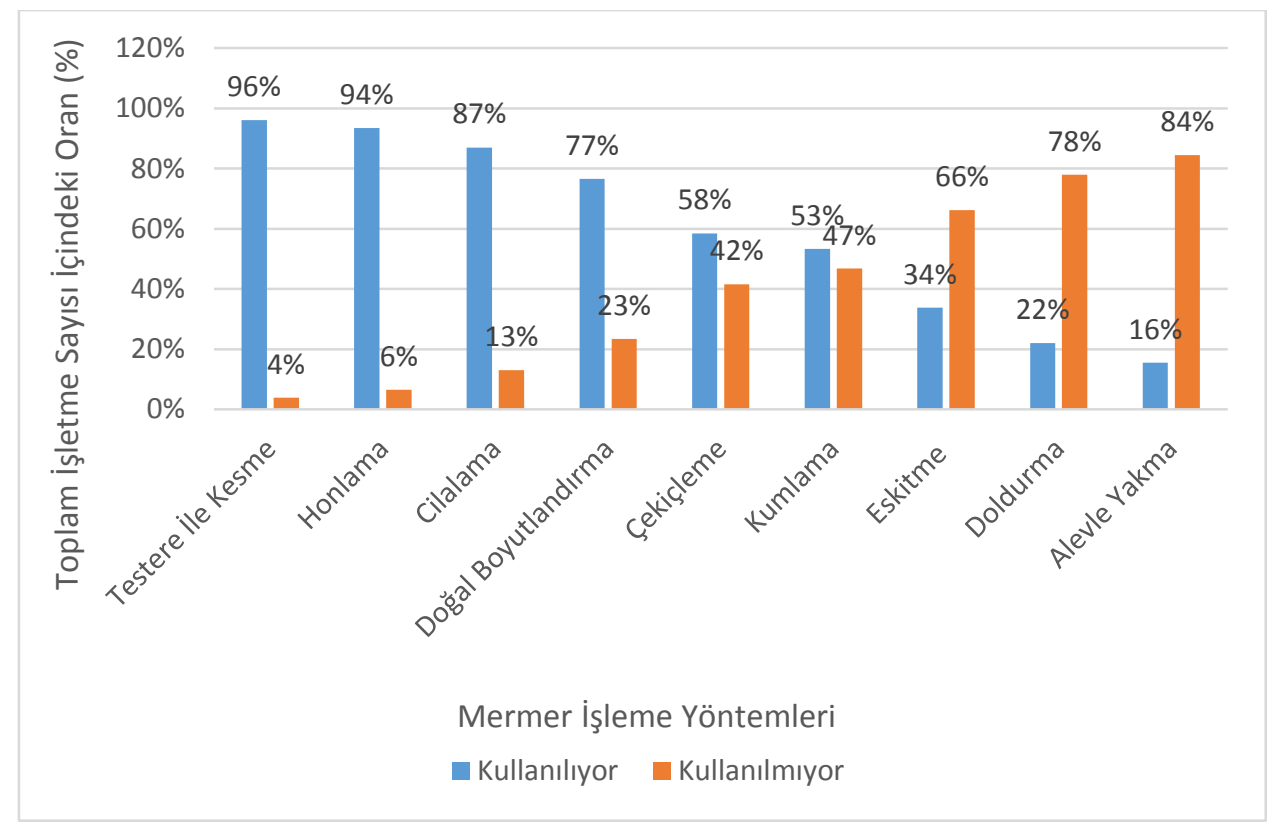

Şekil 7. İşletmelerde mermer işleme yöntemlerinin kullanımına ilişkin dağılım 
Tablo 1. İşletmelerde mermer işleme yöntemlerinin kullanımına ilişkin dağılımın ki-kare uyum iyiliği testi sonuçları

\begin{tabular}{lll}
\hline Mermer İşleme Yöntemi & $\begin{array}{l}\text { İşleme } \\
\text { Işletmelerin Tüm İşletmelere Oranı } \\
(\%)\end{array}$ & $\begin{array}{l}\text { Ki-Kare Uyum İyiliği Test Sonucu } \\
\end{array}$ \\
\hline Testere ile kesme & $\% 96$ & $\mathrm{X}^{2}(1, \mathrm{n}=77)=65,468 ; \mathrm{p}=0,000$ \\
\hline Honlama & $\% 94$ & $\mathrm{X}^{2}(1, \mathrm{n}=77)=58,299 ; \mathrm{p}=0,000$ \\
\hline Cilalama & $\% 87$ & $\mathrm{X}^{2}(1, \mathrm{n}=77)=42,195 ; \mathrm{p}=0,000$ \\
\hline Doğal boyutlandırma & $\% 77$ & $\mathrm{X}^{2}(1, \mathrm{n}=77)=21,831 ; \mathrm{p}=0,000$ \\
\hline Çekiçleme & $\% 58$ & $\mathrm{X}^{2}(1, \mathrm{n}=77)=2,195 ; \mathrm{p}=0,138$ \\
\hline Kumlama & $\% 53$ & $\mathrm{X}^{2}(1, \mathrm{n}=77)=0,325 ; \mathrm{p}=0,569$ \\
\hline Eskitme & $\% 34$ & $\mathrm{X}^{2}(1, \mathrm{n}=77)=8,117 ; \mathrm{p}=0,004$ \\
\hline Doldurma & $\% 22$ & $\mathrm{X}^{2}(1, \mathrm{n}=77)=24,013 ; \mathrm{p}=0,000$ \\
\hline Alevle yakma & $\% 16$ & $\mathrm{X}^{2}(1, \mathrm{n}=77)=36,481 ; \mathrm{p}=0,000$ \\
\hline
\end{tabular}

\section{2. İşletme Temsilcilerinin, İşletmelerinde Mermer Atığı Oluşumuna İlişkin Gözlemleri Hakkındaki Bulgular}

Araştırma kapsamında görüşülen işletme temsilcilerinin \% 58'i işletmelerinde işlenen mermerin en az \% 30'unun, en fazla ise \% 70'inin atık haline geldiğini; \% 21 'i, işletmelerinde işlenen mermerin \% 30'undan daha azının atık haline geldiğini; \% 21 'i ise işletmelerinde işlenen mermerin \% 70’den fazlasının atık haline geldiğini gözlemlediklerini belirtmişlerdir (Şekil 8). Ki-kare uyum iyiliği testi sonucuna göre, işletmelerde işlenen mermerin \% 30 - \% 70'inin atık haline geldiğine ilişkin görüş sayısı beklenen değerden anlamlı bir şekilde fazladır $\left(X^{2}(2, n=77)=21,844 ; p=0,000\right)$.

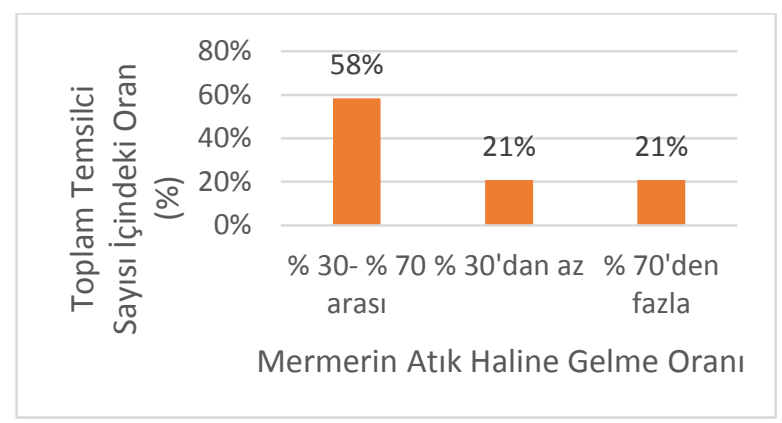

Şekil 8. Mermerin atık haline gelme oranına ilişkin gözlemler

İşletme temsilcilerinin \% 91'i mermer üretiminde atık oluşmasına neden olan ilk faktörün ocak işlemleri olduğunu, \% 8'i mermer üretiminde atık oluşmasına neden olan ilk faktörün fabrika işlemleri olduğunu, \% 1'i ise mermer üretiminde atık oluşmasına neden olan ilk faktörün mermerin doğal yapısı olduğunu gözlemlediklerini belirtmişlerdir (Şekil 9). Ki-kare uyum iyiliği testi sonucuna göre, mermer üretiminde atık oluşmasına neden olan ilk faktörün ocak işlemleri olduğuna ilişkin görüş sayısı beklenen değerden anlamlı bir şekilde fazladır $\left(X^{2}(2, n=77)=115,351 ; p=0,000\right)$. 
İşletme temsilcilerinin \% 88'i mermer üretiminde atık oluşmasına neden olan ikinci faktörün fabrika işlemleri olduğunu, \% 10’u mermer üretiminde atık oluşmasına neden olan ikinci faktörün mermerin doğal yapısı olduğunu, \% 2'si ise mermer üretiminde atık oluşmasına neden olan ikinci faktörün ocak işlemleri olduğunu gözlemlediklerini belirtmişlerdir (Şekil 9). Ki-kare uyum iyiliği testi sonucuna göre, mermer üretiminde atık oluşmasına neden olan ikinci faktörün fabrika işlemleri olduğuna ilişkin görüş sayısı beklenen değerden anlamlı bir şekilde fazladır $\left(X^{2}(2, n=77)=105,688\right.$; $\mathrm{p}=0,000)$.

İşletme temsilcilerinin \% 48'i mermer üretiminde atık oluşmasına neden olan üçüncü faktörün mermerin doğal yapısı olduğunu, \% 47'si mermer üretiminde atık oluşmasına neden olan üçüncü faktörün fabrika işlemleri olduğunu, \% 5'i ise mermer üretiminde atık oluşmasına neden olan üçüncü faktörün mermerin doğal yapısı olduğunu gözlemlediklerini belirtmişlerdir (Şekil 9). Ki-kare uyum iyiliği testi sonucuna göre, mermer üretiminde atık oluşmasına neden olan üçüncü faktörün ocak işlemleri olduğuna ilişkin görüş sayısı beklenen değerden anlamlı bir şekilde azdır $\left(\mathrm{X}^{2}(2\right.$, $\mathrm{n}=77)=27,455 ; \mathrm{p}=0,000)$.

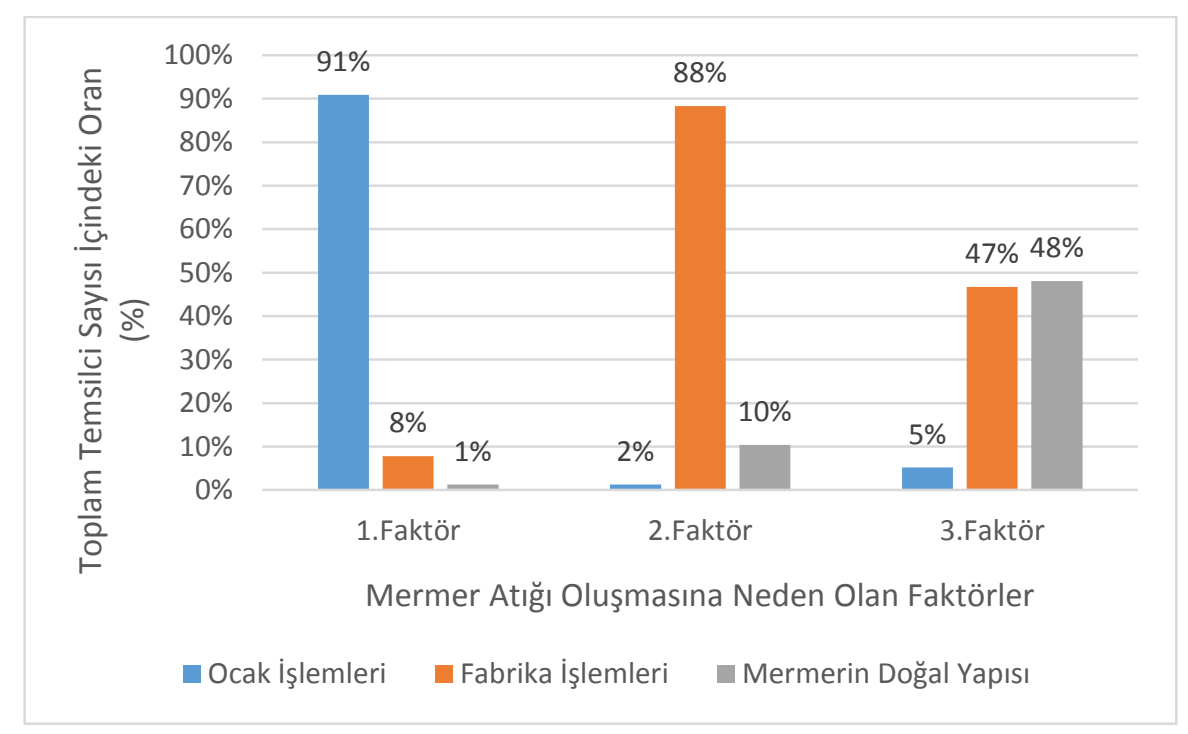

Şekil 9. Mermer atığı oluşmasına neden olan faktörlere ilişkin gözlemler

Araştırma kapsamında işletme temsilcilerinden, mermerin doğal kusurlarının mermer atığı oluşumuna etkisi hakkındaki gözlemlerini belirtmeleri istenmiştir. İşletme temsilcilerinin konuya ilişkin gözlemlerinin dağglımı Şekil 10’da, gözlemlere ilişkin ki-kare uyum iyiliği testi sonuçları ise Tablo 2'de görülmektedir. Elde edilen verilere göre; kırık ve çatlakların mermer atı̆̆ı oluşmasında etkili; mermerdeki boşluk kusurunun mermer atığı oluşmasında kısmen etkili; damar, kristal doku, 
foliasyon ve fosiller gibi kusurların ise mermer atığı oluşmasında etkisiz olduğunu gözlemleyen işletme temsilcilerinin sayısı, beklenen değerden anlamlı bir şekilde fazladır.

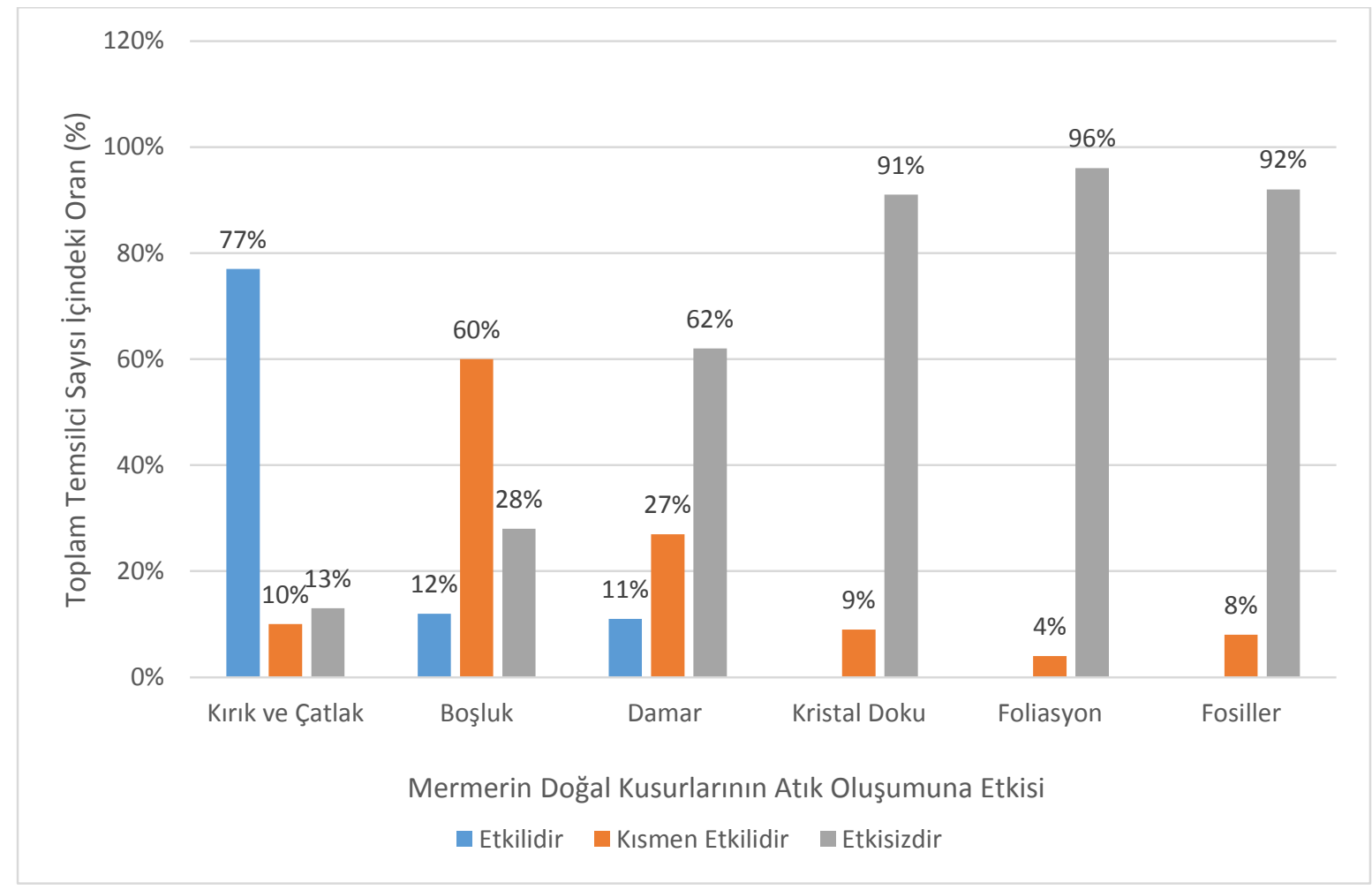

Şekil 10. Mermerin doğal kusurlarının mermer atı̆̆ı oluşumuna etkisi konusundaki gözlemler

Tablo 2. Mermerin doğal kusurlarının mermer atığı oluşumuna etkisi konusundaki gözlemlerin kikare uyum iyiliği testi sonuçları

\begin{tabular}{ll}
\hline Mermerin Doğal Kusuru & Ki-Kare Uyum İyiliği Test Sonucu \\
\hline Kırık ve Çatlak & $\mathrm{X}^{2}(2, \mathrm{n}=77)=65,013 ; \mathrm{p}=0,000$ \\
\hline Boşluk & $\mathrm{X}^{2}(2, \mathrm{n}=77)=27,455 ; \mathrm{p}=0,000$ \\
\hline Damar & $\mathrm{X}^{2}(2, \mathrm{n}=77)=32,442 ; \mathrm{p}=0,000$ \\
\hline Kristal Doku & $\mathrm{X}^{2}(1, \mathrm{n}=77)=51,545 ; \mathrm{p}=0,000$ \\
\hline Foliasyon & $\mathrm{X}^{2}(1, \mathrm{n}=77)=65,468 ; \mathrm{p}=0,000$ \\
\hline Fosiller & $\mathrm{X}^{2}(1, \mathrm{n}=77)=54,870 ; \mathrm{p}=0,000$ \\
\hline
\end{tabular}

Araştırma kapsamında işletme temsilcilerinden, işletmelerinde çıkan mermer atığı türüne göre atık miktarına ilişkin gözlemlerini belirtmeleri istenmiştir. İşletme temsilcilerinin konuya ilişkin gözlemlerinin dağılımı Şekil 11'de, gözlemlere ilişkin ki-kare uyum iyiliği testi sonuçları ise Tablo 3'te görülmektedir. Elde edilen verilere göre; moloz atı̆̆ın yüksek düzeyde; kapak atığın düşük düzeyde; mermer tozu türündeki atığın düşük düzeyde olduğunu gözlemleyen işletme temsilcilerinin 
sayısı, beklenen değerden anlamlı bir şekilde fazladır. Paledyen atığın orta düzeyde olduğunu gözlemleyen işletme temsilcilerinin sayısı ise beklenen değerden anlamlı bir fark göstermemiştir.

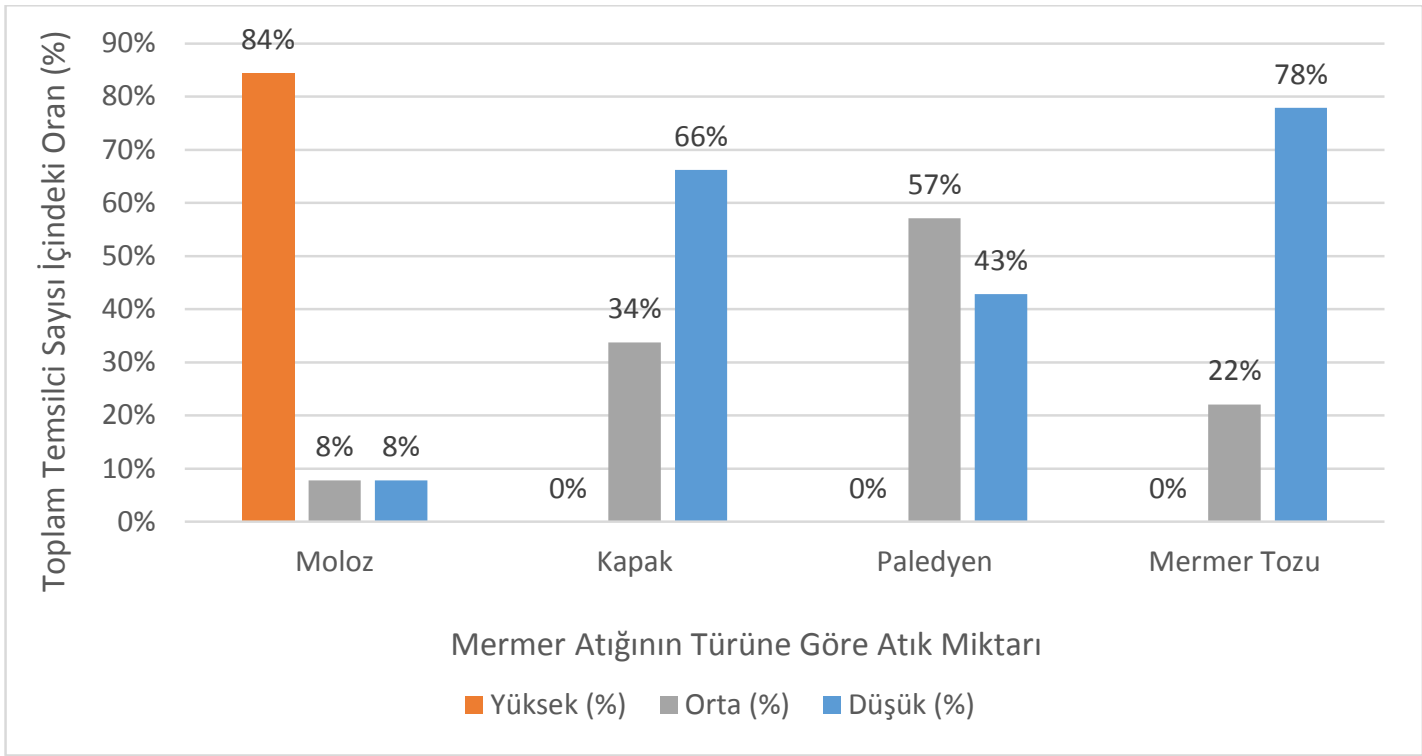

Şekil 11. Mermer atığının türüne göre atık miktarına ilişkin gözlemler

Tablo 3. Mermer atığının türüne göre atık miktarına ilişkin gözlemlerin ki-kare uyum iyiliği testi sonuçları

\begin{tabular}{ll}
\hline Mermer Atığının Türü & Ki-Kare Uyum İyiliği Test Sonucu \\
\hline Moloz & $\mathrm{X}^{2}(2, \mathrm{n}=77)=90,416 ; \mathrm{p}=0,000$ \\
\hline Kapak & $\mathrm{X}^{2}(1, \mathrm{n}=77)=8,117 ; \mathrm{p}=0,004$ \\
\hline Paledyen & $\mathrm{X}^{2}(1, \mathrm{n}=77)=1,571 ; \mathrm{p}=0,210$ \\
\hline Mermer Tozu & $\mathrm{X}^{2}(1, \mathrm{n}=77)=24,013 ; \mathrm{p}=0,000$ \\
\hline
\end{tabular}

Temsilcisi ile görüşülen işletmelerde ortaya çıkan mermer atıklarının değerlendirilip değerlendirilmediğine ilişkin soruya işletme temsilcilerinin \% 82'si hayır, \% 18'i ise evet yanıtı vermişlerdir. Ki-kare uyum iyiliği testi sonucuna göre, mermer atığını değerlendirmeyen işletme sayısının, beklenen değerden anlamlı bir şekilde fazla olduğu görülmektedir $\left(\mathrm{X}^{2}(1, \mathrm{n}=77)=31,182\right.$; $\mathrm{p}=0,000$ ). Temsilcilerin ifade ettiğine göre, mermer atı̆̆ını değerlendiren 14 firmanın 9'u mermer atıklarının moloz olarak satışından gelir elde etmektedir.

\section{3. İşletme Temsilcilerinin, İşletmelerinde Oluşan Mermer Atığının Değerlendirilmesine İlişkin Düşünceleri Hakkındaki Bulgular}

Araştırma kapsamında işletme temsilcilerine, mermer atıklarının doğrudan yapı malzemesi üretiminde kullanım olanakları konusundaki düşüncelerini saptamak amacıyla bir soru yöneltilmiştir. 
Literatürde, üretiminde mermer atığı kullanılabileceği belirtilen yapı malzemesi seçenekleri katılımcılara sunulmuş, katılımcılardan sözü edilen kullanımın olanaklı olup olmadığı konusundaki düşüncelerini “evet” veya "hayır" ifadesi ile belirtmeleri istenmiştir. İşletme temsilcilerinin konuya ilişkin düşüncelerinin dağılımı Şekil 12'de, gözlemlere ilişkin ki-kare uyum iyiliği testi sonuçları ise Tablo 4'te görülmektedir. Elde edilen verilere göre; katılımcılar mermer atıklarının tuğla, boya, çelik ve plastik yapı malzemelerinin üretiminde kullanılamayacağını düşünmektedir. Diğer yandan mermer atıklarının gazbeton, parke taşı, cam, kompozit malzeme ve derz dolgusu üretiminde kullanılamayacağını düşünen temsilci sayısı da, beklenen değerden anlamlı bir şekilde fazladır. Mermer atıklarının suni mermer ve seramik üretiminde kullanılabileceğini düşünen temsilcilerin sayısı, beklenen değerden anlamlı bir fark göstermemiştir. Mermer atıklarının beton ve kireç üretiminde kullanılabileceğini düşünen temsilci sayısı ise, beklenen değerden anlamlı bir şekilde fazladir.

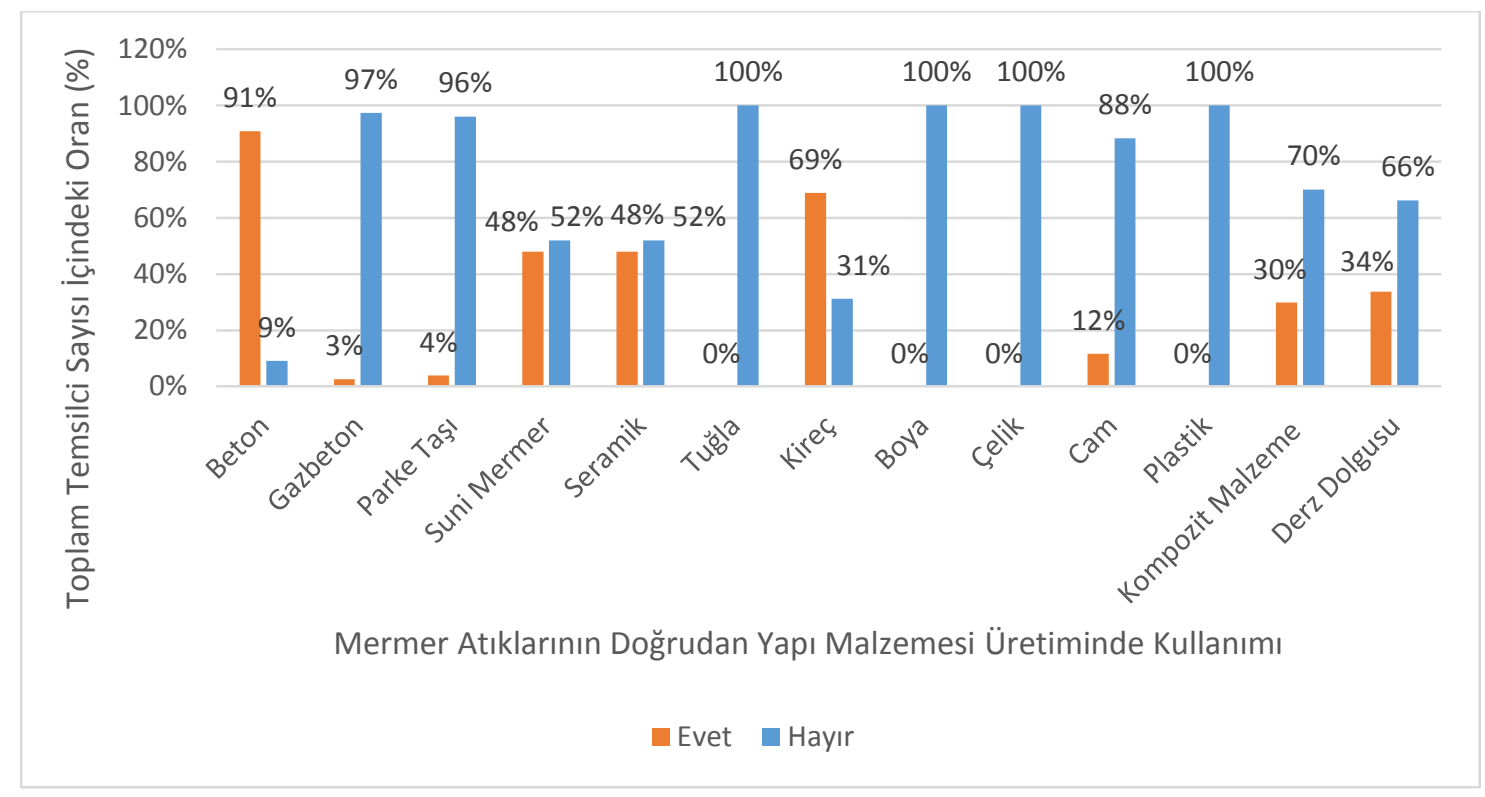

Şekil 12. İşletme temsilcilerinin mermer atıklarının doğrudan yapı malzemesi üretiminde değerlendirilmesi konusundaki düşünceleri 
Tablo 4. İşletme temsilcilerinin mermer atıklarının doğrudan yapı malzemesi üretiminde değerlendirilmesi konusundaki düşüncelerinin ki-kare uyum iyiliği testi sonuçları

\begin{tabular}{ll}
\hline Yap1 Malzemesi Üretimine İlişkin Seçenekler & Ki-Kare Uyum İyiliği Test Sonucu \\
\hline Beton & $\mathrm{X}^{2}(1, \mathrm{n}=77)=51,545 ; \mathrm{p}=0,000$ \\
\hline Gazbeton & $\mathrm{X}^{2}(1, \mathrm{n}=77)=69,208 ; \mathrm{p}=0,000$ \\
\hline Parke Taş1 & $\mathrm{X}^{2}(1, \mathrm{n}=77)=65,468 ; \mathrm{p}=0,000$ \\
\hline Suni Mermer & $\mathrm{X}^{2}(1, \mathrm{n}=77)=0,117 ; \mathrm{p}=0,732$ \\
\hline Seramik & $\mathrm{X}^{2}(1, \mathrm{n}=77)=0,117 ; \mathrm{p}=0,732$ \\
\hline Kireç & $\mathrm{X}^{2}(1, \mathrm{n}=77)=10,922 ; \mathrm{p}=0,001$ \\
\hline Cam & $\mathrm{X}^{2}(1, \mathrm{n}=77)=45,208 ; \mathrm{p}=0,000$ \\
\hline Kompozit Malzeme & $\mathrm{X}^{2}(1, \mathrm{n}=77)=12,481 ; \mathrm{p}=0,000$ \\
\hline Derz Dolgusu & $\mathrm{X}^{2}(1, \mathrm{n}=77)=8,117 ; \mathrm{p}=0,004$ \\
\hline
\end{tabular}

Araştırma kapsamında işletme temsilcilerine, mermer atıklarının yapı sektöründe kullanım olanakları konusundaki düşüncelerini saptamak amacıyla da bir soru yöneltilmiştir. Literatürde, yapı sektöründe mermer atığı kullanılabileceği belirtilen uygulama seçenekleri “zemin stabilizasyonu” ve “ahşap yüzey şekillendirmesi” olmak üzere iki başlık halinde sunulmuş, katılımcılardan sözü edilen kullanımın olanaklı olup olmadığı konusundaki düşüncelerini “evet” veya "hayır” ifadesi ile belirtmeleri istenmiştir. Elde edilen verilere göre katılımcıların tümü mermer atıklarının zemin stabilizasyonunda kullanılabileceğini, ahşap yüzey şekillendirmesinde ise kullanılamayacağını düşünmektedir.

Araştırma kapsamında işletme temsilcilerine yöneltilen bir diğer soru ise mermer atıklarının yapı sektörü dışındaki sektörlerde kullanım olanakları konusundaki düşüncelerini saptamak amacıyla yöneltilmiştir. Literatürde, mermer atığı kullanılabileceği belirtilen metalürji, kimya, kağıt, şeker, kozmetik sektörleri, zirai kireçtaşı-zirai toprak ve zemin ayarlayıcı üretimi ile hayvan yemi üretimi ve gübre üretimi gibi sektörler seçenek olarak sunulmuştur. Katılımcılardan sözü edilen kullanımın olanaklı olup olmadığı konusundaki düşüncelerini "evet" veya "hayır" ifadesi ile belirtmeleri istenmiştir. İşletme temsilcilerinin konuya ilişkin düşüncelerinin dağılımı Şekil 13’te, gözlemlere ilişkin ki-kare uyum iyiliği testi sonuçları ise Tablo 5'te görülmektedir. Elde edilen verilere göre; mermer atıklarının metalürji ve kimya sektörleri ile zirai kireçtaşı-zirai toprak, zemin ayarlayıcı ve gübre üretiminde kullanılabileceğini düşünen temsilcilerin sayısı, beklenen değerden anlamlı bir fark göstermemiştir.

Mermer atıklarının kağıt, şeker ve kozmetik sektörlerinde kullanılamayacağını düşünen temsilci sayısı, beklenen değerden anlamlı bir şekilde fazladır. Buna karşın mermer atıklarının hayvan 
yemi üretiminde kullanılabileceğini düşünen temsilci sayısı, beklenen değerden anlamlı bir şekilde fazladır.

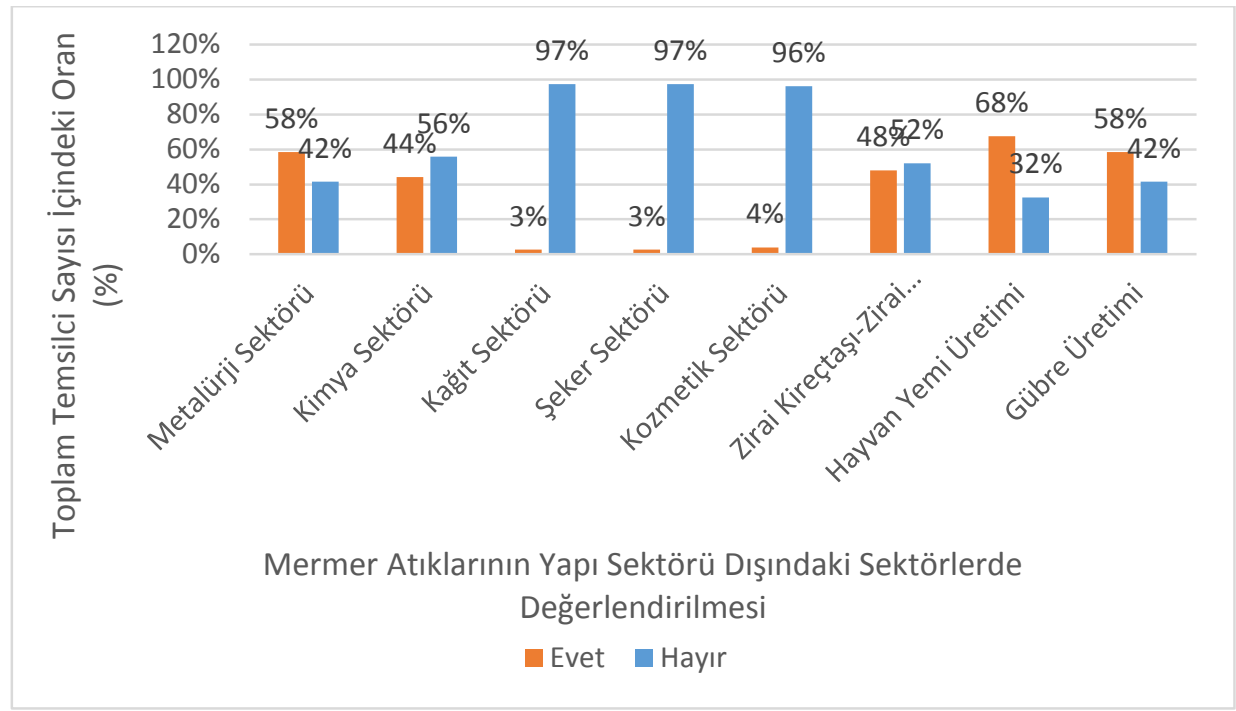

Şekil 13. İşletme temsilcilerinin mermer atıklarının yapı sektörü dışındaki sektörlerde değerlendirilmesi konusundaki düşünceleri

Tablo 5. İşletme temsilcilerinin mermer atıklarının yapı sektörü dışındaki sektörlerde değerlendirilmesi konusundaki düşüncelerinin ki-kare uyum iyiliği testi sonuçları

\begin{tabular}{ll}
\hline $\begin{array}{l}\text { Mermer Atığı Kullanılabilecek Sektörlere } \\
\text { İlişkin Seçenekler }\end{array}$ & Ki-Kare Uyum İyiliği Test Sonucu \\
\hline Metalürji Sektörü & $X^{2}(1, n=77)=2,195 ; p=0,138$ \\
\hline Kimya Sektörü & $X^{2}(1, n=77)=1,052 ; p=0,305$ \\
\hline Kâğıt Sektörü & $X^{2}(1, n=77)=69,208 ; p=0,000$ \\
\hline Şeker Sektörü & $X^{2}(1, n=77)=69,208 ; p=0,000$ \\
\hline Kozmetik Sektörü & $X^{2}(1, n=77)=65,468 ; p=0,000$ \\
\hline $\begin{array}{l}\text { Zirai Kireçtaş1-Zirai Toprak ve Zemin } \\
\text { Ayarlayıc1 }\end{array}$ & $X^{2}(1, n=77)=0,117 ; p=0,732$ \\
\hline Hayvan Yemi Üretimi & $X^{2}(1, n=77)=9,468 ; p=0,002$ \\
\hline Gübre Üretimi & $X^{2}(1, n=77)=2,195 ; p=0,138$ \\
\hline
\end{tabular}

\section{4. İlişkisel Bulgular}

Araştırma kapsamında, temsilcisi ile görüşülen ulusal mermer işletmelerinin özellikleri, işletme temsilcilerinin atık oluşumuna ilişkin gözlemleri ve yine işletme temsilcilerinin mermer atıklarının değerlendirilmesi konusundaki düşünceleri arasında ki-kare bağımsızlık testleri yapılmıştır. Aralarında istatistiksel açıdan anlamlılık bulunan değişkenlere ilişkin test sonuçları, ilişkisel bulgular bağlamında, aşağıda sunulmuştur.

Yapılan araştırmada, temsilcisi ile görüşülen işletmelerde mermer atıklarının değerlendirilip değerlendirilmemesi ile işletmede blok mermer satışının olup olmaması arasında pozitif yönde, orta 
kuvvette ve istatistiksel açıdan anlamlı bir ilişki olduğu görülmüştür $\left(X^{2}\right.$ YATES $(1, n=77)=6,210$; $\mathrm{p}=0,006 ; \phi=0,318)$.

Temsilcisi ile görüşülen işletmelerde mermer atıklarının değerlendirilip değerlendirilmemesi ile işletmede atık satışından gelir elde edilip edilmemesi arasında negatif yönde, kuvvetli ve istatistiksel açıdan anlamlı bir ilişki olduğu tespit edilmiştir ( $\mathrm{X}^{2}$ YATES $(1, \mathrm{n}=77)=38,844$; $\left.\mathrm{p}_{\text {FISHER }}=0,000 ; \phi=-0,772\right)$.

Araştırma kapsamında temsilcisi ile görüşülen işletmelerde mermer atıklarının değerlendirilip değerlendirilmemesi ile temsilcilerin mermer atıklarının gazbeton üretiminde kullanılıp kullanılamayacağı konusundaki görüşleri arasında pozitif yönde, orta kuvvette ve istatistiksel açıdan anlamlı bir ilişki olduğu belirlenmiştir $\left(\mathrm{X}^{2}\right.$ YATES $\left.(1, \mathrm{n}=77)=4,456 ; \mathrm{p}_{\text {FISHER }}=0,031 ; \phi=0,346\right)$.

Temsilcisi ile görüşülen işletmelerde mermer atıklarının değerlendirilip değerlendirilmemesi ile işletme temsilcilerinin işletmede mermer atı̆̆ı oluşmasına neden olan 2. faktör olarak değerlendirdikleri unsurlar arasında orta kuvvette ve istatistiksel açıdan anlamlı bir ilişki olduğu tespit edilmiştir $\left(X^{2}(2, n=77)=7,059\right.$; p pISHER=0,028; V=0,303).

\section{Sonuç ve Öneriler}

TÜYAP Bursa 4. Uluslararası Blok Mermer Fuarı'na katılan ulusal mermer işletmelerinden 77 adedinin temsilcileri ile görüşülerek gerçekleştirilen bu araştırma sonucunda elde edilen bulgular değerlendirilerek aşağıdaki sonuç ve önerilere ulaşılmıştır:

- Marmara Bölgesi'nde faaliyet gösteren, 2001 yılı sonrası kurulan, yılda 10000 m3’ün üzerinde üretim ve satış yapan, hem blok hem de levha mermer üretimi yapan; testere ile kesme, honlama, cilalama, doğal boyutlandırma, eskitme, doldurma ve alevle yakma gibi mermer işleme yöntemlerini kullanan işletme sayısı beklenen değerden anlamlı bir şekilde fazladir.

- Üretime giren mermerin \% 30 - \% 70’u arasındaki bir oranda atık haline geldiğini gözlemleyen temsilci sayısı, beklenen değerden anlamlı bir şekilde fazladır. Bu bulgu üretime giren mermerin \% 70'inin atık haline geldiğine dair literatür bulgusu ile çelişmektedir. Literatür bulgusu sayısal verilere dayanmaktadır (Onargan, 2007; Sağlam Çitoğlu ve Bayraktar, 2018). İşletme temsilcilerinin atık oranına ilişkin gözlemlerinin, literatürdeki sayısal veriden farklı oluşu, işletmeyi temsil eden çalışanların konu ile ilgili bilgi, dikkat, algı ve duyarlılıkları üzerinde durulmasının faydalı olacağını düşündürmektedir. 
- Mermer üretiminde atık oluşmasına neden olan ilk faktörün ocak işlemleri, ikinci faktörün ise fabrika işlemleri olduğunu gözlemleyen temsilci sayısı beklenen değerden anlamlı bir şekilde fazladır. Mermerin doğal kusurlarından kırık ve çatlakların mermer atığı oluşmasında etkili; mermerdeki boşluk kusurunun mermer atığı oluşmasında kısmen etkili; damar, kristal doku, foliasyon ve fosiller gibi kusurların ise mermer atığı oluşmasında etkisiz olduğunu gözlemleyen temsilci sayısı da beklenen değerden anlamlı bir şekilde fazladır. Moloz atığın yüksek düzeyde; kapak atığın düşük düzeyde; mermer tozu türündeki atığın ise düşük düzeyde olduğunu gözlemleyen işletme temsilcilerinin sayısı beklenen değerden anlamlı bir şekilde fazladır. Bulgular literatür verileri ile benzerlik göstermektedir.

- Mermer atığını değerlendirmeyen işletme sayısı, beklenen değerden anlamlı bir şekilde fazladır. Diğer yandan, temsilcisi ile görüşülen işletmelerde mermer atıklarının değerlendirilip değerlendirilmemesi ile işletme temsilcilerinin işletmede mermer atığı oluşmasına neden olan 2. faktör olarak değerlendirdikleri unsurlar arasında orta kuvvette ve istatistiksel açıdan anlamlı bir ilişki olduğu belirlenmiştir. Ankete verilen yanıtlar karşılaştırmalı olarak incelendiğinde, işletmede mermer atığı oluşmasına neden olan 2. faktörün fabrika işlemleri olduğunu düşünen temsilcilerin çoğunlukta olduğu ve sözü edilen temsilcilerin çoğunluğunun da işletmelerindeki mermer atıklarının değerlendirilmediğini belirttikleri görülmüştür. İşletmede mermer atığı oluşmasına neden olan önemli faktörlerden birinin fabrika işlemleri olduğu gözlemlendiği halde mermer atıklarının değerlendirilmiyor olması da dikkat çekicidir. Atığın değerlendirilmesinin önündeki engeller araştırılmalı ve çözüm önerileri geliştirilmelidir.

- Katılımcıların tamamı mermer atıklarının tuğla, boya, çelik ve plastik yapı malzemelerinin üretiminde kullanılamayacağını düşünmektedir. Diğer yandan mermer atıklarının gazbeton, parke taşı, cam, kompozit malzeme ve derz dolgusu üretiminde kullanılamayacağını düşünen temsilci sayısı, beklenen değerden anlamlı bir şekilde fazladır. Ayrıca mermer atıklarının suni mermer ve seramik üretiminde kullanılabileceğini düşünen temsilcilerin sayısı da beklenen değerden anlamlı bir fark göstermemiştir. Benzer şekilde, mermer atıklarının kağıt, şeker ve kozmetik sektörlerinde kullanılamayacağını düşünen temsilci sayısı, beklenen değerden anlamlı bir şekilde fazladır. Yine mermer atıklarının metalürji ve kimya sektörleri ile zirai kireçtaşı-zirai toprak, zemin ayarlayıcı ve gübre üretiminde kullanılabileceğini düşünen temsilcilerin sayısı da beklenen değerden anlamlı bir fark göstermemiştir. Diğer yandan araştırmada, temsilcisi ile görüşülen işletmelerde mermer atıklarının değerlendirilip 
değerlendirilmemesi ile temsilcilerin mermer atıklarının gazbeton üretiminde kullanılıp kullanılamayacağı konusundaki görüşleri arasında pozitif yönde, orta kuvvette ve istatistiksel açıdan anlamlı bir ilişki olduğu tespit edilmiştir. Ankete verilen yanıtlar karşılaştırmalı olarak incelendiğinde atık değerlendirmesi yapmayan işletmelerde görev yapan temsilcilerin mermer atıklarının gazbeton üretiminde kullanılamayacağını düşündükleri anlaşılmıştır. Literatürde, anılan tüm yap1 malzemelerinin üretiminde ve yap1 dış1 sektörlerde mermer atıklarının kullanılabileceği belirtildiği halde, araştırmaya katılan işletme temsilcilerinin düşüncelerinin literatür verileri ile örtüşmüyor olması dikkat çekicidir. İşletme temsilcilerinin düşüncelerinin literatür verileri ile neden uyum göstermediği araştırılmalıdır.

- İşletmelerde mermer atıklarının değerlendirilme durumu ile blok mermer satışı olup olmaması arasında pozitif yönde, orta kuvvette anlamlı bir ilişkinin bulunmuş olması, blok mermer satışı yapan işletmelerin atık değerlendirmesi konusuna levha mermer satışı yapan işletmelerden daha fazla önem verdiğini düşündürmektedir. Bu bulgu, ortaya çıkan atığın niteliği ve miktarı açısından irdelendiğinde literatür verileri ile örtüşmektedir.

- Temsilcisi ile görüşülen işletmelerde mermer atıklarının değerlendirilip değerlendirilmeme durumu ile mermer atığı satışından gelir elde edilip edilmeme durumu arasında negatif yönde, kuvvetli ve anlamlı bir ilişki olduğu görülmektedir. Ankete verilen yanıtlar karşılaştırmalı olarak incelendiğinde, işletmelerinde mermer atıklarının değerlendirilmediğini ifade eden işletme temsilcilerinin, işletmelerinin mermer atıklarından gelir elde ettiğini belirttikleri görülmüştür. Elde edilen sonuç, işletme temsilcilerinin mermer atığı satışını, mermer atığının değerlendirilmesi olarak görmediklerini göstermektedir.

\section{Yazarların Katkısı}

Çalışmada her iki yazar da eşit oranda katkı sunmuştur.

\section{Çıkar Çatışmasıı Beyanı}

Yazarlar arasında herhangi bir çıkar çatışması bulunmamaktadır.

\section{Araştırma ve Yayın Etiği Beyanı}

Yapılan çalışmada, araştırma ve yayın etiğine uyulmuştur. 


\section{Kaynaklar}

Akın, E. (2007). Mermer Tozlarının Uçucu Kül ile Polimer Esaslı Kompozit Malzeme Üretiminin Araştırılması [Yüksek Lisans Tezi]. [Ankara]: Gazi Üniversitesi Fen Bilimleri Enstitüsü, İleri Teknolojiler Anabilim Dal1 Anabilim Dal1.

Akkoyun, Ö. ve Ankara, H. (2007). Kalite Maliyet Modelleri ve Mermer Fabrikaları İçin Bir Uygulama. Madencilik, 46 (1), 3-14.

Arel, H. Ş., (2016). Recyclability of Waste Marble in Concrete Production. Journal of Cleaner Production. 131, 179-188.

Bilensoy, M. (2010). Mermer Fabrikaları Toz Atıklarının Değerlendirilmesi [Yüksek Lisans Tezi]. [Eskişehir]: Eskişehir Osmangazi Üniversitesi Fen Bilimleri Enstitüsü, Maden Mühendisliği Anabilim Dalı.

Bilgin, Ö., Koç, E. (2013). Mermer Madenciliğinde Çevresel Etkiler. Madencilik Türkiye. [Erişim Adresi: www.madencilik-turkiye.com]

Boztaş, S.C. (2009). Burdur İli Yeşilova İlçesi Kağılcık Mevkii Kireçtaşlarının Mermer Olarak Kullanılabilirliğinin Araştırılması [Yüksek Lisans Tezi]. [Adana]: Çukurova Üniversitesi Fen Bilimleri Enstitüsü, Maden Mühendisliği Anabilim Dalı Anabilim Dalı.

Ceylan, H. (2000). Mermer Fabrikalarındaki Mermer Toz Atıklarının Ekonomik Olarak Değerlendirilmesi [Yüksek Lisans Tezi]. [Isparta]: Süleyman Demirel Üniversitesi Fen Bilimleri Enstitüsü, Maden Mühendisliği Anabilim Dalı.

Ceylan, H., Mança, S. (2013). Mermer Parça Atıklarının Beton Agregası Olarak Değerlendirilmesi. SDU Teknik Bilimler Dergisi, 3(2): 21-25.

Dağlı, Ç. (2014). Mermer Toz Atıklarının Derz Dolgu Malzemesi Olarak Kullanılabilirliğinin Araştırılması [Yüksek Lisans Tezi]. [Diyarbakır]: Dicle Üniversitesi Fen Bilimleri Enstitüsü, Maden Mühendisliği Anabilim Dalı Anabilim Dalı.

Ersoy, B., Sayın, Z.E., Arsoy, Z., Sayın, Ü. (2015). Yeterince Farkında Olamadığımız Atıl Kaynağımız: Doğaltaş Ocak ve Fabrika Atıkları. Maden Ocak Teknolojileri, 5(27):92-100.

Filiz, M. , Özel, C., Soykan, O. ve Ekiz, Y. (2010). Atık Mermer Tozunun Parke Taşlarında Kullanılması. Yapı Teknolojileri Elektronik Dergisi, 6(2): 57-72.

Geçgil, Ş., (1988). Eczacı, İlaç, Gıda ve Kozmetik Konuları ile İlgili Yasa Yönetmelik Kararnamesi ve Bildirgeler. İstanbul: Marmara Üniversitesi Eczacılık Fakültesi Yayını.

Günaydın, O., Güçlüer, K. ve Ünal, O. (2016). Adıyaman Atık Mermer Tozlarının Gazbeton Üretiminde Kullanılabilirliğinin Araştırılması. Yapı Teknolojileri Elektronik Dergisi, 12(1): 21-29.

Kavas, T. ve Kibıcı, Y. (2001). Afyon Bölgesi Mermer Atıklarının Portland Kompoze Çimentosu Üretiminde Katkı Maddesi Olarak Kullanım Olanakları. Y. Kibıcı ve diğerleri (Ed.), Türkiye III. Mermer Sетровуити MERSEM'2001 Afyon, 328-333. 
Şimşek, S., ve Perker, Z.S., Uluslararası Doğu Anadolu Fen Mühendislik ve Tasarım Dergisi / International Journal of Eastern Anatolia Science Engineering and Design (IJEASED)

(2022) 4(1): 32-52

Keleştemur, O., Arıcı, E., Yıldız, S. ve Gökçer, B. (2014). Performance Evaluation of Cement Mortars Containing Marble Dust and Glass Fiber Exposed to High Temperature by Using Taguchi Method. Construction and Building Materials, 60, 17-24.

Kocabăg, D. (2018). Sürdürülebilir Madencilik Bağlamında Mermer Sanayi ve Mermer Atıklarının Değerlendirilmesi: Mermer Madenciliğinde Çevresel Yaklaşımlar. T. Güler ve E. Polat (Ed.), Muğla Büyükşehir Belediyesi Kültür Yayınları, Muğla, 51-92.

Maden Atıkları Yönetmeliği. T.C. Resmi Gazete. 15.7.2015. Sayı:29417, Erişim Adresi: https://www.resmigazete.gov.tr/eskiler/2015/07/20150715-3.htm.

Onargan, T., (2007). Mermer Madenciliğinde Çevre Yönetimi. II. Madencilik ve Çevre Sempozyumu. Ankara, $61-75$.

Sağlam Çitoğlu,G., Bayraktar, O.Y. (2018). Atık Mermer Tozu ve İnşaat Sektöründeki Kullanımı İle İlgili Çalışmalar. 2nd International Symposium on Innovative Approaches in Scientific Studies, Samsun, 1323-1330.

Sofuoğlu, S. D., Ordu, M., Aykaç ,E. ve Çelikbaş, S. (2013). Mermer ve Traverten Tozunun Ahşap Üst Yüzey İşlemlerinde Kullanın Parlaklık ve Pürüzlülüğüne Etkisi. Dumlupınar Üniversitesi Fen Bilimleri Enstitüsü Dergisi, 30(2013):81-93.

Sütçü, M., Alptekin, H., Erdoğmuş, E., Er, Y. ve Gencel, O. (2015). Characteristics of Fired Clay Bricks with Waste Marble Powder Addition as Building Materials. Construction and Building Materials, 82, 1-8.

Taner, A.H. (2012). Mermer Atıklarının Karşılaştırılmalı Değirmende Mikronize Öğütülebilirliğinin Araştırılması [Yüksek Lisans Tezi]. [Zonguldak]: Bülent Ecevit Üniversitesi Fen Bilimleri Enstitüsü, Maden Mühendisliği Anabilim Dalı.

Taşgın, Y. (2014). Mermer, Ferrokrom Cürufu ve Cam Atıklarının Asfalt Beton Kaplamalarında Filler Olarak Kullanılabilirliğinin Araştırılması [Yüksek Lisans Tezi]. [Tunceli]: Tunceli Üniversitesi Fen Bilimleri Enstitüsü, Çevre Mühendisliği Anabilim Dalı.

Tennich, M., Kallel, A. ve Ouezdou, M.B. (2015). Incorporation of Fillers From Marble and Tile Wastes in the Composition of Self-Compacting Concretes. Construction and Building Materials, 91, 65-70.

Topçu, İ. B., Bilir, T. ve Uygunoğlu, T. (2009). Effect of Waste Marble Dust Content as Filler on Properties of Self-Compacting Concrete. Construction and Building Materials, 23, 1947-1953.

Ulubeyli, G. C. ve Artır, C. (2015). Properties of Hardened Concrete Produced by Waste Marble Powder. Procedia - Social and Behavioral Sciences, 195, 2181 - 2190.

Yıldız, A. H. (2008). Mermer Toz Atıklarının Yol İnşaatlarında Değerlendirilmesi [Doktora Tezi]. [Isparta]: Süleyman Demirel Üniversitesi Fen Bilimleri Enstitüsü, İnşaat Mühendisliği Anabilim Dalı.

Zhang L. (2013). Production of bricks from waste materials - a review. Construction and Building Materials, 47, 643-655. 